\title{
OPTIMIZATION OF KEY PARAMETERS IN STRUVITE (K) PRODUCTION FOR PHOSPHORUS AND POTASSIUM RECOVERY USING A BATCH CRYSTALLIZER
}

\author{
D. S. Perwitasari ${ }^{1}$, S. Muryanto ${ }^{2}$, M. Tauviqirrahman ${ }^{3}$, J.Jamari ${ }^{3}$, and \\ A.P. Bayuseno ${ }^{3}{ }^{*}$ \\ ${ }^{1}$ Department of Chemical Engineering, Universitas Pembangunan National "Veteran" Jawa \\ Timur, Surabaya, Indonesia \\ ${ }^{2}$ Department of Chemical Engineering, UNTAG University in Semarang, Indonesia \\ ${ }^{3}$ Department of Mechanical Engineering, Diponegoro University, Tembalang Campus, \\ Semarang, Indonesia \\ *E-mail:apbayuseno@gmail.com
}

\begin{abstract}
Struvite $(\mathrm{K})$ precipitation can be used for recovering the valuable nutrients, mainly phosphorus $(\mathrm{P})$ and potassium (K) from wastewater. In this study, the key parameters controlling its precipitation in a batch crystallizer, namely temperature $\left(30-40{ }^{\circ} \mathrm{C}\right)$, stirring rate $(200-400 \mathrm{rpm})$, citric acid concentration $(1-20 \mathrm{ppm})$ were optimized using SRM (surface response methodology) for yielding the optimum mass of the struvite (K) crystal. The XRPD Rietveld method confirmed that struvite $(\mathrm{K})$ and impurity of sylvite $(\mathrm{KCl})$ were precipitated from the $\mathrm{pH}$ solution of 9 . The most significant factor corresponding to the yield response was predicted by SRM to be temperature, while the stirring rate and the citric acid concentration are insignificant factors contributing to the optimal mass yields. The optimum mass of precipitates $(14.682 \mathrm{mg}$ ) was obtained, when the precipitation process was set at the temperature of $39^{\circ} \mathrm{C}$, a stirring rate of $376 \mathrm{rpm}$ and citric acid concentration of $2.2350 \mathrm{ppm}$. These parameters would be the best design factors for yielding the optimum struvite (K) crystal with the purity of more than $99 \mathrm{wt} . \%$.

Keywords: P and K-recovery, Struvite (K), Surface Response Methodology (SRM), Citric Acid, XRPD Rietveld Analysis

(C) RASĀYAN. All rights reserved
\end{abstract}

\section{INTRODUCTION}

Magnesium ammonium phosphate (MAP) could precipitate from an aqueous solution leading to the scale deposition of struvite $\left(\mathrm{MgNH}_{4} \mathrm{PO}_{4} \cdot 6 \mathrm{H}_{2} \mathrm{O}\right)$ minerals, which have detrimental effects of the process on pipes, pumps, tanks, and other industrial equipment ${ }^{1,2}$. This formation of hard scale can hinder a stream flow, which in turn requires the periodic cleaning of pipelines. However, the use of chemical agents (e.g., $\mathrm{KOH}$ and $\mathrm{MgCl}_{2}$ ) in the wastewater may provide the benefit of MAP precipitation, which can recover potassium, phosphate, and ammonia to prevent eutrophication in an efficient way ${ }^{1,3-5}$. Additionally, the use of crystallization technology may recover valuable nutrients contained in wastewater through the precipitation of struvite and/or struvite $(\mathrm{K})\left(\mathrm{KMgPO}_{4} \cdot 6 \mathrm{H}_{2} \mathrm{O}\right)$ with improved morphology and homogeneous particle size ${ }^{6}$.

More recently, the MAP crystallization offers an efficient way of phosphate recovery from the wastewater at high energy efficiency and productivity of solids manufacturing ${ }^{5,7}$. This method has been widely applied for phosphate removal from calf manure, and different wastewater ${ }^{8,9}$. The MAP with the molar ratio of 1:1:1 can crystallize in the form of struvite according to the reaction below $(1)^{1}$ :

$$
\mathrm{Mg}^{2+}+\mathrm{NH}_{4}^{+}+\mathrm{HnPO}_{4}^{n-3}+6 \mathrm{H}_{2} \mathrm{O} \rightarrow \mathrm{MgNH}_{4} \mathrm{PO}_{4}\left(\mathrm{H}_{2} \mathrm{O}\right)_{6}+n \mathrm{H}^{+}
$$

Rasayan J. Chem., 12(2), 787-795(2019)

http://dx.doi.org/10.31788/RJC.2019.1225125

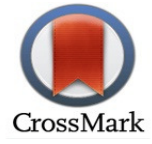


Corresponding to the equation (1), $\mathrm{pH}$, supersaturation, temperature, and foreign ions present in the solution may control the degree of struvite precipitation and the property of the crystal formed ${ }^{10-13}$. Specifically, the solution temperature may control the solubility of struvite including the change in enthalpy during the struvite crystallization. In some case, the temperature increases resulting in the increased reaction rate of struvite formation.

Conversely, the struvite crystallization from the solution could be inhibited by chemical additives of inorganic and organic compounds ${ }^{14-16}$. Obviously, the presence of inhibitors was shown to decrease the kinetics of the reaction and hence decreasing in the crystallization process of struvite ${ }^{17}$. For example, the use of citrate and phosphocitrate additives in synthetic wastewater can inhibit significantly the struvite formation, which in turn results in alterations in size and structure of crystals ${ }^{18}$. Moreover, citric acids could be a negative effect on struvite formation, while carboxylic acids (tartaric and maleic acids) have less influence on struvite crystallization ${ }^{19}$. Correspondingly, the MAP crystallization reaction could be completely inhibited by the presence of citric acid with high concentration. Moreover, the MAP precipitation with citric and succinic acid present in the solution leads to the change in morphology and size of the crystallized products ${ }^{20,21}$. Correspondingly, tight aggregates of crystals with fine and uniform morphology would have good solubility in water, which is favorable for use as fertilizer. Accordingly, particle size and size distribution of the struvite products have become greatly concerned about adding the chemical additives ${ }^{7}$.

Further, struvite formation may be inhibited by inducing vibration flow, turbulent flow or stirring process $^{9}$. For example, a mechanical stirrer may be used for preparing the stock solution, which is stirred for obtaining a possible homogeneous solution. Here, the stirring rate may control the nucleation and subsequent crystal growth of struvite. When the stirring rate is higher, the nucleation of struvite occurs rapidly ${ }^{22}$. Correspondingly, the struvite crystal grows faster on the existing nucleation sites as the mixing energy is generated at the higher stirring rate $(>500 \mathrm{rpm})^{23}$. Therefore, the degree of mixing should be constrained because this is the main factor of increasing in struvite deposited on the bottom of tanks. Additionally, the stirring rate should be controlled in order to yield the optimum mass deposit with the required crystal size.

Also, a sustainable way of MAP precipitation has been proposed to recover phosphate and potassium in wastewater by adding magnesium through simultaneous crystallization of struvite $(K)^{24}$. Struvite $(K)$ has been known as an equivalent structure of struvite; in which the $\mathrm{NH}_{4}{ }^{+}$cations are replaced by the cation $\mathrm{K}^{+}$. This is because the ionic radii of $\mathrm{K}^{+}(1.33 \AA)$ are almost the same that of $\mathrm{NH}_{4}^{+}(1.43 \AA)$. Accordingly, struvite $(\mathrm{K})$ has the same crystal structure as struvite ${ }^{25}$. Struvite $(\mathrm{K})$ crystallizes in the solution represented as:

$$
\mathrm{Mg}^{2+}+\mathrm{K}^{-}+\mathrm{PO}_{4}^{3-}+6 \mathrm{H}_{2} \mathrm{O} \rightarrow \mathrm{KMgPO}_{4} \cdot 6\left(\mathrm{H}_{2} \mathrm{O}\right)_{(\text {solid })}
$$

Based on the equation (2), when $\mathrm{KOH}$ is added to the solution containing $\mathrm{Mg}^{2+}$ and $\mathrm{PO}_{4}{ }^{3-}$, struvite $(\mathrm{K})$ would be formed. Moreover, the $\mathrm{PO}_{4}{ }^{3-}$ activity and $\mathrm{pH}$ may control the struvite $(\mathrm{K})$ precipitation. Values of $\mathrm{pH}$ in the range of 9 to 10.5 were reported for maximum phosphate recovery in the struvite $(\mathrm{K})$ precipitation. ${ }^{10,19}$

Importantly, the effective recovery of potassium and phosphates in the wastewater treatment needs a comprehensive analysis of crystallization parameters and their optimization to yield purity and crystal productivity. The optimized process parameters are addressed here to complete quality data of crystallized products, which can be mainly characterized by their microstructures namely mineralogy and morphology ${ }^{7}$. In that respect, however, no report is found in the literature on the optimization of the crystallization parameters in the potassium and phosphate recovery as struvite (K). Here, mineralogical characterization (qualitative and quantitative) of struvite $(\mathrm{K})$ precipitated in the complex wastewater has been not performed in detail. Additionally, the quantitative mineralogical analysis can be used an effective control in the purity of minerals precipitated in the solution.

In this work, the results of the optimized struvite $(\mathrm{K})$ production in the batch crystallizer is presented. The key variables such as temperatures, citric acid concentrations, and stirring rates were optimized using SRM (surface response methodology) to provide the optimum mass of struvite (K) formed in the system. The crystalline phase was determined by X-ray powder diffraction (XRPD) method, while morphology 
and chemical element analysis were performed by SEM/EDX. These characterization results are expected to provide important insights into the ways for the struvite $(\mathrm{K})$ formed at diverse natural and laboratory conditions, and eventually, to improve understanding for the potassium and phosphorus recovery in wastewater.

\section{Struvite (K) Synthesis Experiments}

\section{EXPERIMENTAL}

The crystal-forming solutions for the synthesis experiments were prepared by mixing a solution of $\mathrm{MgCl}_{2} \cdot 6 \mathrm{H}_{2} \mathrm{O}$ and $\mathrm{NH}_{4} \mathrm{H}_{2} \mathrm{PO}_{4}$. In this way, each powder of $\mathrm{MgCl}_{2} \cdot 6 \mathrm{H}_{2} \mathrm{O}$ and $\mathrm{NH}_{4} \mathrm{H}_{2} \mathrm{PO}_{4}$ with analytical grade chemicals (Merck, Germany), without further purification was dissolved in double-distilled water. Here $500 \mathrm{ml}$ of $0.30 \mathrm{M}\left(\mathrm{MgCl}_{2} \cdot 6 \mathrm{H}_{2} \mathrm{O}\right.$ and $\left.\mathrm{NH}_{4} \mathrm{H}_{2} \mathrm{PO}_{4}\right)$ were prepared accordingly. Moreover, the solution with $\mathrm{pH} 9$ was prepared by diluting $0.5 \mathrm{~N} \mathrm{KOH}$ solution, while the amount (ppm) of citric acid was diluted into $\mathrm{MgCl}_{2}$ solution. Varying temperatures (30, 35, and $\left.40{ }^{\circ} \mathrm{C}\right)$, stirring rate $(200,300$, and 400 $\mathrm{rpm})$, citric acid concentrations $(1,10$, and $20 \mathrm{ppm})$ were determined as independent variables to be optimized. Temperature range $\left(30-40^{\circ} \mathrm{C}\right)$ was selected in this work according to the mesophilic temperature range, which is commonly operated in an anaerobic digester ${ }^{7}$.

The precipitation process was performed in $500 \mathrm{ml}$ volume of Pyrex glass vessel mechanically agitated at varying stirring rates. The stock solution was continuously stirred to ensure homogeneity of the solution, whereas the completion of the precipitation was finished in 90 minutes. The precipitation process was monitored by $\mathrm{pH}$ meter, thereby changing in the $\mathrm{pH}$ solution could be observed. The obtained slurries were then separated through a paper filter, whereas the obtained precipitates were dried at room temperature for $48 \mathrm{~h}$ and subsequently were weighed using Sartorius weigh-scale.

\section{Crystallography and Morphological Analysis of Struvite (K)}

Crystallography analysis of struvite (K) was conducted on XRPD data which were recorded using X-ray diffractometer with Bragg-Brentano geometry (Philips 1830/40). The XRPD sample was measured using the selected parameters $\left(5-90^{\circ} 2 \theta, 0.020 \mathrm{steps}, 10 \mathrm{~s} / \mathrm{step}\right)$. PC-based search- match program (MATCH) was employed for qualitative phase analysis of the XRPD data, while the identified phase was subsequently validated by the Rietveld method (Program Fullprof-2k, version 3.30). ${ }^{26,27}$ The Rietveld refinement of XRPD data employed the crystal structure model obtained from the literature (AMCSD-the American crystal structure database). The refined scale factors and cell parameters were eventually employed for phase quantitative analysis (wt.\%), which could be run by its self computer program.

For the morphological and elemental analysis by SEM/EDX (JEOL JSM 5200), the fine powder of the precipitate $(<100 \mu \mathrm{m})$ was placed in epoxy on an Al-sample holder and its surface was then sputtered with carbon.

\section{Design of Experiment and Parameter Optimization of Crystallization}

In this present study, the input variables of temperature, stirring rate, and the citric acid concentrationwere optimized by SRM to yield the optimum response of the precipitate mass (mg) (Table-1). Here a multiple regression data analysis of the parameters employed a statistical program (StatSoft, Tulsa, OK, USA). Moreover, the optimum response of mass yielded from the crystallization were found by solving the regression equation of selected input variables and also by examining plots of the response surface contour according to the following equation (3):

$$
\mathrm{Y}=\beta_{\mathrm{O}}+\sum_{j=1}^{k} \beta_{j} X_{j}+\sum \sum_{i<j} \beta_{i j} X_{i} X_{j}+\sum_{j=1}^{k} \beta_{i j} X_{j}^{2}+\varepsilon
$$

Where, $\mathrm{Y}$ is the yield; $\beta_{O}, \beta_{j}, \beta_{\mathrm{ij}}$ and $\beta_{\mathrm{jj}}$ are constants; $X_{i}$ and $X_{j}$ are the independent variables or factors; $\varepsilon$ is a random error.

\section{Phase and Morphology of the Crystalline Product}

\section{RESULTS AND DISCUSSION}

The XRPD results of crystalline products were obtained from the experiments after being validated by the Rietveld method are presented in Fig.-1. The Rietveld method confirmed that struvite (K) with sylvite 
$(\mathrm{KCl})$ impurity was obviously precipitated in the aqueous solution with $1 \mathrm{ppm}$ citric acid addition, which was prepared by a mechanical stirrer at $400 \mathrm{rpm}$ and set-up at $40{ }^{\circ} \mathrm{C}$ (Fig.1a). The evidence of struvite (K) crystals developed in the synthetic solution due to the addition of acetic acid $(0,1,10$ and $20 \mathrm{ppm})$ is given in Figure 1b. Obviously, the purity of struvite (K) (>99 wt. \%) was obtained in the crystallized products as confirmed by the XRPD phase quantitative analysis. Given this result, the crystallization of struvite $(\mathrm{K})$ may have great potential for a full complement of fertilizer containing nitrogen, phosphate and potassium. This process could also provide an economic return when the yield of struvite (K) is sold for decreasing phosphate fertilizer demands ${ }^{7}$.

Further, the EDS spectrum consisted of the highest peaks of $\mathrm{K}, \mathrm{Mg}, \mathrm{P}$ and $\mathrm{O}$ corresponding to chemical elements of struvite (K) (Fig.-2). Moreover, its morphology was shown to be irregular prismatic likeshape crystal, which is known as struvite $(\mathrm{K})^{28}$. The purity of struvite $(\mathrm{K})$ was also confirmed as no traces of other compounds could be found, instead of carbon element present in the coated sample. Moreover, the precipitation yielded relatively small $(5-10 \mu \mathrm{m})$ struvite $(\mathrm{K})$ crystallites aggregated into the larger $(50$ $100 \mu \mathrm{m})$ particles. Correspondingly, the more citric acid was added, the smaller crystalline would be obtained. Here, this smaller particle size could be a positive effect on a slow-release fertilizer?
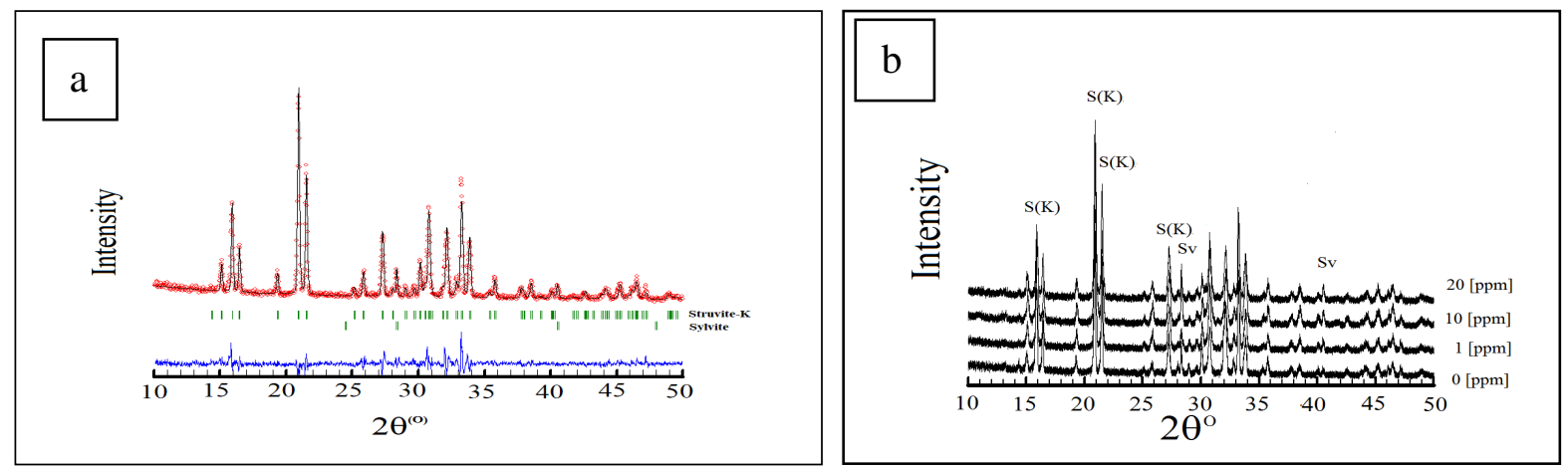

Fig.-1: (a) The Rietveld Refinement Results for XRPD Analysis of the Precipitates; Black Line (Final Refinement); Red Circle (Experimental Data) and Different Plot Between Both; (b) XRPD Patterns of the Precipitates Obtained From the Solutions with 0,1 ppm, 10 ppm, 20 ppm Citric Acid Addition. The Stock Solution was stirred at $400 \mathrm{rpm}$ and a Temperature of $40^{\circ} \mathrm{C}$. The Peaks are $\mathrm{S}(\mathrm{K})$ Struvite-(K) and Sv (Sylvite) respectively
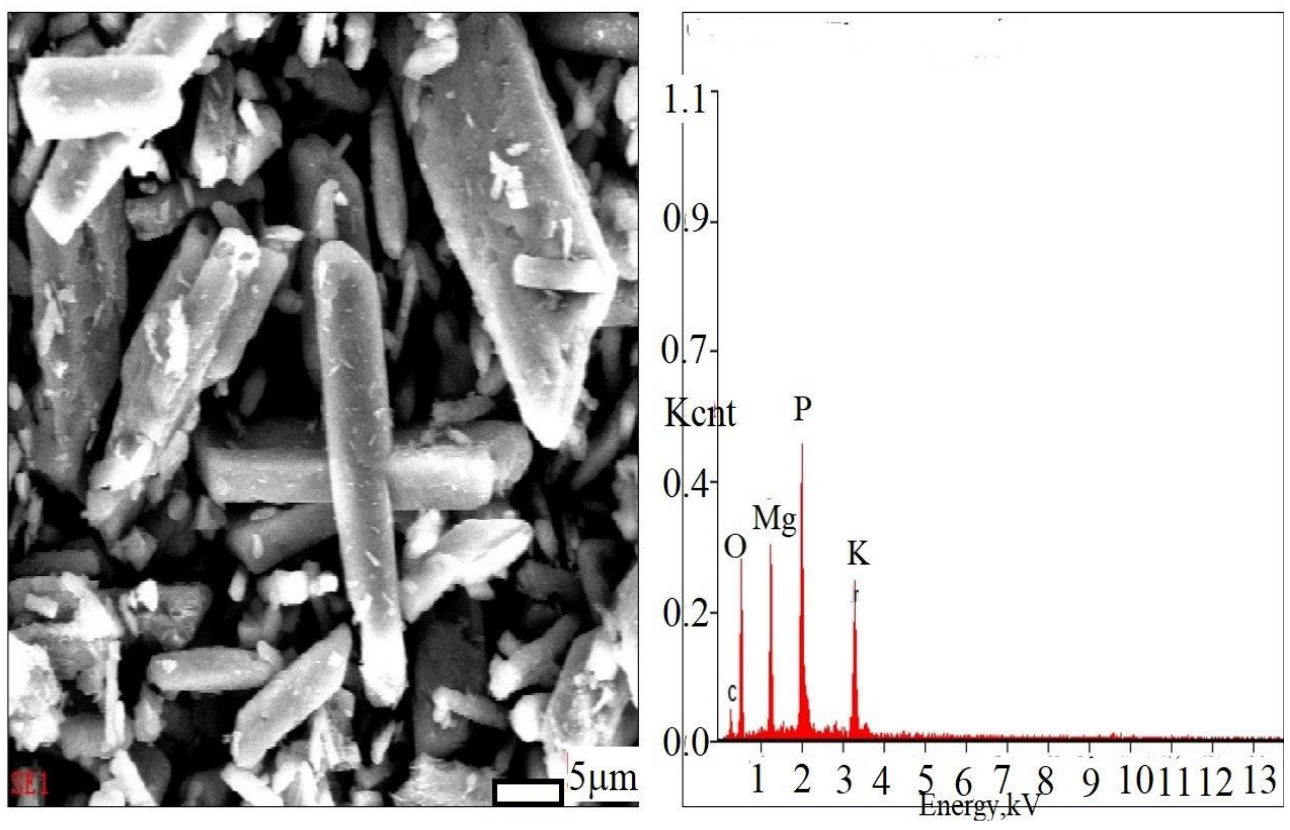

Fig.-2: SEM/EDX Analysis Results of Precipitating Solid at $40{ }^{\circ} \mathrm{C}$ with $10 \mathrm{ppm}$ Additive. 


\section{Response Model of SRM and Statistical Analysis}

SRM optimization of the model of response variables employed the input data (Table-1), which are composed of 3 factorial design $2^{(3)}$. Accordingly, variables and experimental domains such as temperature $\left(\mathrm{X}_{1}, 30-40{ }^{\circ} \mathrm{C}\right)$, stirring rate $\left(\mathrm{X}_{2}, 200-400 \mathrm{ppm}\right)$ and citric acid concentration $\left(\mathrm{X}_{3}, 1-20 \mathrm{ppm}\right)$ were adopted for the analysis. Moreover, factors and their levels for SRM relates to the low level (-1) (30, 200, 1), high level $(+1)(40,400,20)$, and the center point $(0)(35,300,10)$. The mass of struvite $(\mathrm{K})$ obtained from all the experiments is presented in Table-2. Here the second-order polynomial equation (Eq.3) could be fitted with the mathematical model for the regression analysis of independent variables. Therefore, optimum struvite production (Y) follows the equation (Eq. 4):

$Y=2.413689+0.2945 X_{1}-0.003781 X_{1}^{2}+0.023532 X_{2}-0.000033 X_{2}^{2}-0.247095 X_{3}-0.0033 X_{3}^{2}+$ $0.000144 X_{1} X_{2}+0.009784 X_{1} X_{3}-0.000259 X_{2} X_{3}$

Table-1: Design of Experiment for the Independent Variables and their Levels

\begin{tabular}{c|c|c|c}
\hline Independent Variables & $\begin{array}{c}\text { Low } \\
\text { Level(-1) }\end{array}$ & $\begin{array}{c}\text { Range and Level Center } \\
\text { Level }(0)\end{array}$ & $\begin{array}{c}\text { High Level } \\
(+1)\end{array}$ \\
\hline Temperature $\left({ }^{\circ} \mathrm{C}\right)$ & 30 & 35 & 40 \\
\hline Stirring rate $(\mathrm{rpm})$ & 200 & 300 & 400 \\
\hline Citric acid Concentration $(\mathrm{ppm})$ & 1 & 10 & 20 \\
\hline
\end{tabular}

Table-2: Design of Experiments for the Independent Variables

\begin{tabular}{c|c|c|c|c}
\hline Run & Temperature $\left({ }^{\circ} \mathrm{C}\right)$ & $\begin{array}{c}\text { Independent variables } \\
\text { Stirring rate }(\mathrm{rpm})\end{array}$ & $\begin{array}{c}\text { Citric acid } \\
\text { Concentration }(\mathrm{ppm})\end{array}$ & $\begin{array}{c}\text { Responses } \\
\text { mass scale } \\
(\mathrm{mg})\end{array}$ \\
\hline 1 & 30.0000 & 200.0000 & 1.0000 & 12.13757 \\
2 & 30.0000 & 200.0000 & 20.0000 & 11.79078 \\
3 & 30.0000 & 400.0000 & 1.0000 & 13.83301 \\
4 & 30.0000 & 400.0000 & 20.0000 & 11.40545 \\
5 & 40.0000 & 200.0000 & 1.0000 & 12.90823 \\
6 & 40.0000 & 200.0000 & 20.0000 & 13.33209 \\
7 & 40.0000 & 400.0000 & 1.0000 & 13.75595 \\
8 & 40.0000 & 400.0000 & 20.0000 & 14.37247 \\
9 & 26.5910 & 300.0000 & 10.0000 & 11.02013 \\
10 & 43.4089 & 300.0000 & 10.0000 & 14.98899 \\
11 & 35.0000 & 131.8207 & 10.0000 & 10.86599 \\
12 & 35.0000 & 468.1793 & 10.0000 & 13.79448 \\
13 & 35.0000 & 300.0000 & -5.97703 & 13.83301 \\
14 & 35.0000 & 300.0000 & 25.9770 & 10.94306 \\
15 & 35.0000 & 300.0000 & 10.0000 & 13.60182 \\
16 & 35.0000 & 300.0000 & 10.0000 & 13.60182 \\
\hline
\end{tabular}

Furthermore, the analysis results of variance (ANOVA) to determine a factor that influences the response are given in Table 3. Here, the significance of the factor affecting the response was derived from $F$-value and $p$-value. The best fitting of using quadratic regression model shows the value of the coefficient $\left(\mathrm{R}^{2}\right)$ of 0.968 , whereas there is no significant lack of fit $(p>0.05) .95 \%$ of the results could be fitted by the calculated model, while only $3.2 \%$ of the total variation did not fit the model. The $F$-test was also selected to confirm a significant factor of the model, in which $F$-value was calculated from the ratio between MSF (mean squares of the factor) of the MSE (mean squares of error). A factor has a significant effect when the $F$-value is greater than the $F$ - table. It is shown in Table-3 that the value of the $F$-the table is less than $F$-value.

The experimental results of all parameters were also presented in chart Pareto (Figure 3). Obviously, all factors have insignificance to the response because of the $p$-value $<0.05$. It can also be seen that the temperature $\left(\mathrm{X}_{1}\right)$ is linear $(\mathrm{L})$ parameter including stirring rate $(\mathrm{L})\left(\mathrm{X}_{2}\right)$ controlling struvite production, whereas citric acid concentration $\left(\mathrm{X}_{3}\right)$; and their quadratic effects $(\mathrm{Q})$ for stirring rate $\left(\mathrm{X}_{2}\right)^{2}$; citric acid 
RASĀYAN J. Chem.

Vol. 12 | No. 2 |787-795| April - June | 2019

concentration $\left(\mathrm{X}_{3}\right)^{2}$ and temperature $\left(\mathrm{X}_{1}\right)^{2}$ were insignificant for the response $\mathrm{Y}$. Here, the quadratic effect of temperature $\left(\mathrm{X}_{1}\right)^{2}$ is shown to be insignificant versus the yield response.

Table-3: ANOVA Analysis of the Yield Response

\begin{tabular}{c|c|c|c|c|c|c}
\hline Source & $\begin{array}{c}\text { Sum of } \\
\text { Squares (SS) }\end{array}$ & $\begin{array}{c}\text { Degree of } \\
\text { Freedom } \\
\text { (DF) }\end{array}$ & $\begin{array}{c}\text { Mean } \\
\text { Square } \\
(\mathrm{MS})\end{array}$ & $F$-Value & $F$-Table & $\mathrm{R}^{2}$ \\
\hline S.S. & 22.77678 & 9 & 22.77678 & 30.1689 & 4.1 & 0.968 \\
Regression & 4.52985 & 6 & 0.75498 & & & \\
S.S. Error & 27.30663 & 15 & & & \\
S.S. Total & & 6 & & & \\
\hline
\end{tabular}

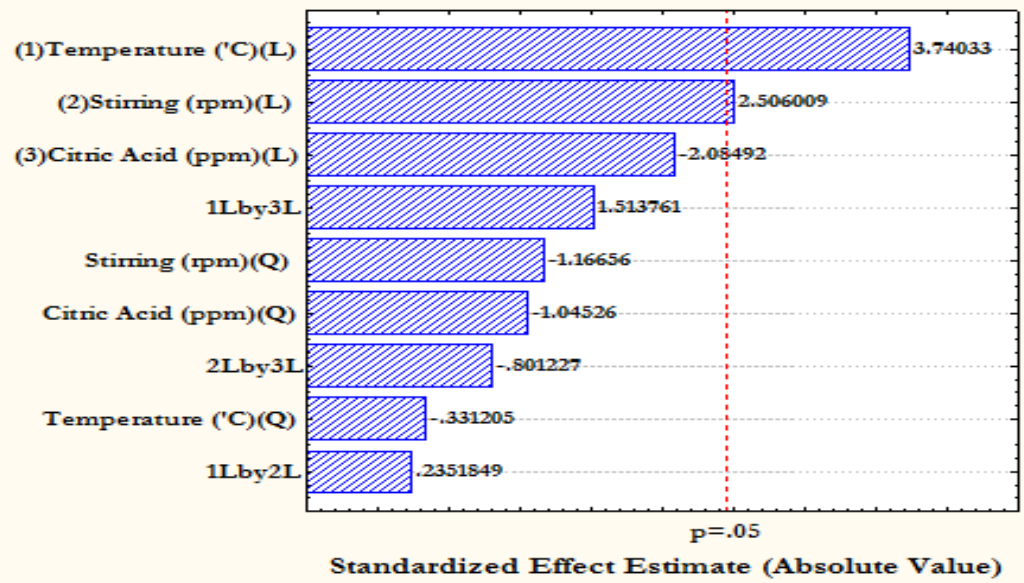

Fig.-3: Pareto Chart of Optimization Independent Variables for Optimum Struvite (K) Production. The Linear (L) and $(\mathrm{Q})$ the Quadratic Represent the Interaction of Variables

\section{The response surfaces for optimizing struvite $(\mathrm{K})$ yield}

The optimized product of struvite (K) (mass in $\mathrm{mg}$ ) by SRM is presented as 3D and 2D contour plots (Figs.-4 to 6). The interaction factors between the stirring rate and citric acid concentration look forward to quite an efficient yield of struvite (K) (Fig.-4). As expected, the mass of struvite (K) increased when the highest stirring rate was applied. However, the presence of increasing citric acid concentration made the reduced production of struvite $(\mathrm{K})$.
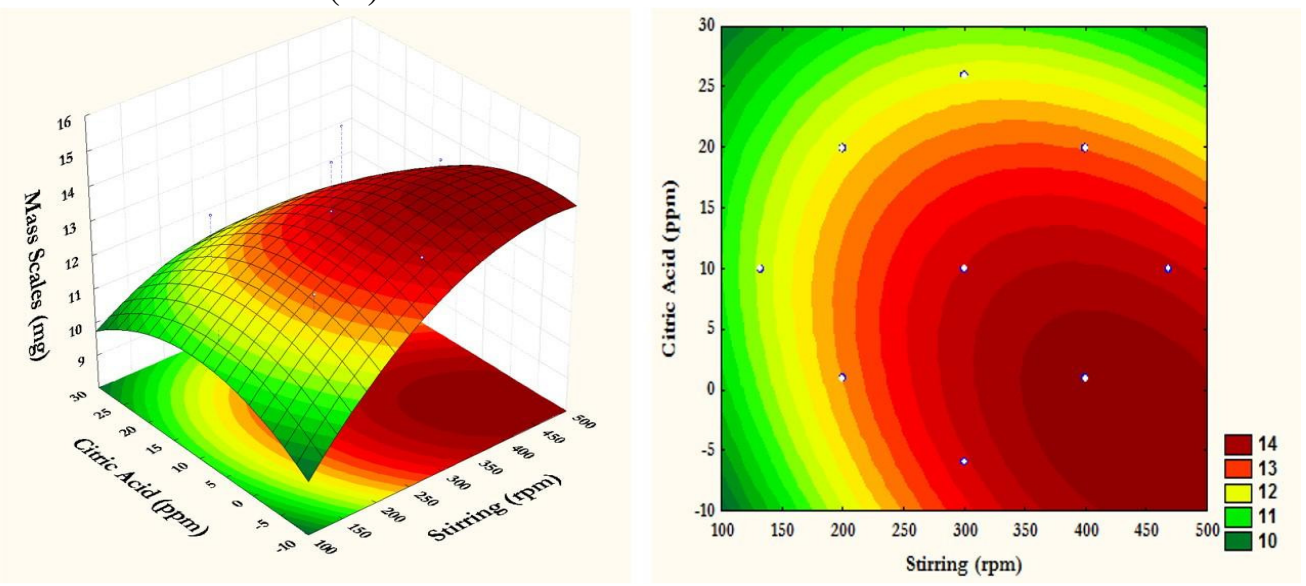

Fig.- 4: RSM Plots of Stirring Rate and Citric Acid Concentration Corresponding to Yield of Mass Crystal

The interaction between temperature and stirring rate against the response of struvite $(K)$ is also given in Fig.-5. When the temperature and stirring rate increased to around $39^{\circ} \mathrm{C}$ and $376 \mathrm{rpm}$, respectively, the 
high amount of struvite $(\mathrm{K})$ could be produced. Conversely, reducing in temperature and stirring rate made the reduced production of struvite. Accordingly, both temperature and stirring rate are key factors controlling the yield of struvite (K). Apparently, the temperature increased from 35 to $40{ }^{\circ} \mathrm{C}$ leads to an increase in the struvite (K) production (Fig.-6). Conversely, the more citric acid added resulted in the decrease the struvite $(\mathrm{K})$ production. These results are the best compromise between temperature and citric acid concentration for optimizing the yield of struvite $(\mathrm{K})$ with controlled morphology and particle size. However, a lot of work remains to be done for recovery of potassium and phosphate in the variation of citric acid additive and temperatures. This further work is required for assuring the quality of struvite (K) meeting a standard in the industrial fertilizer.
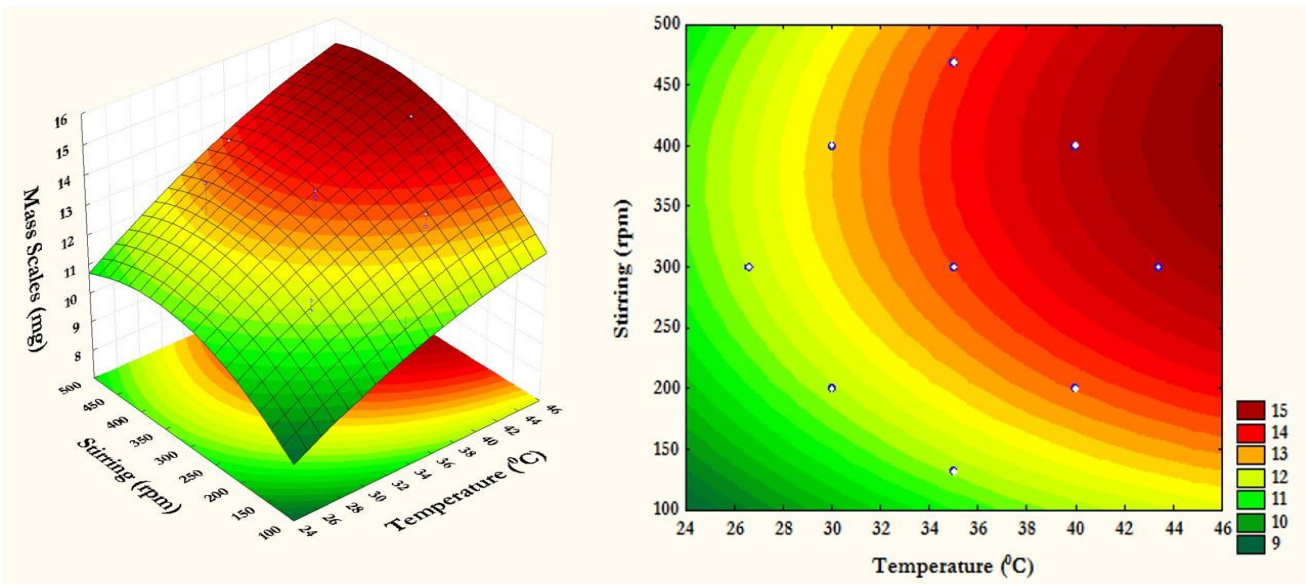

Fig.- 5: RSM Plots of Temperature and Stirring Rate Corresponding to Yield of Mass Crystal
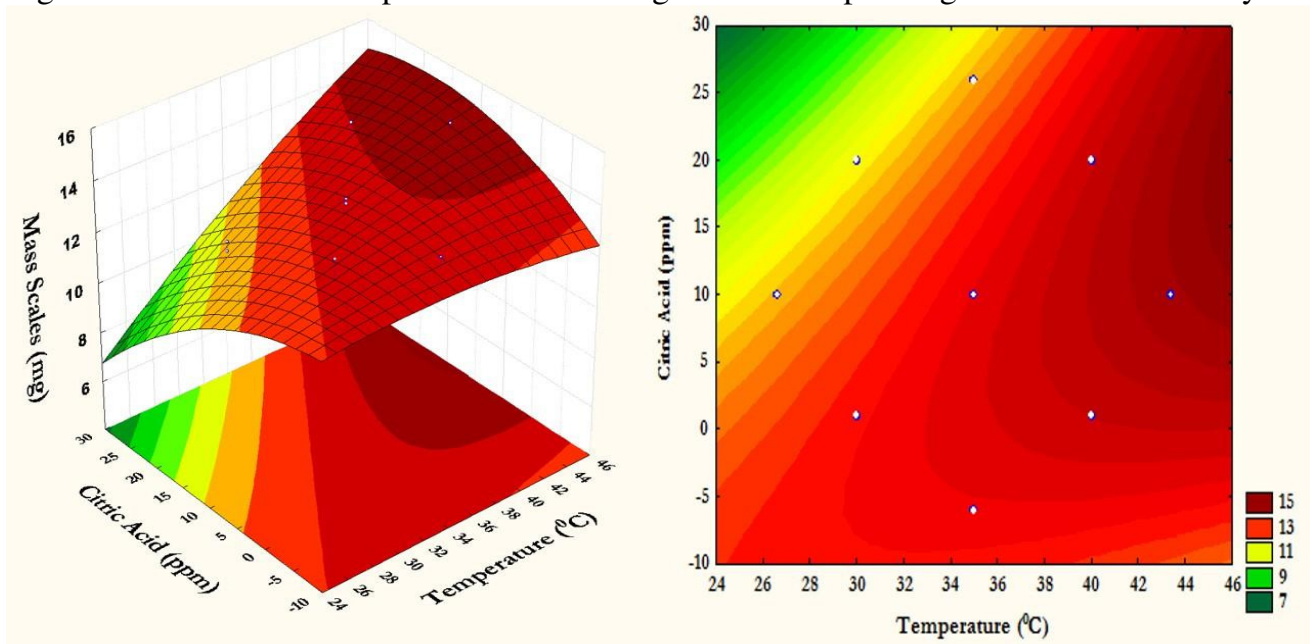

Fig.-6: RSM Plots of Temperature and Citric Acid Concentration Corresponding to Yield of Mass Crystal

Further, the optimum mass of struvite $(\mathrm{K})$ was validated by entering all optimized parameters into the proposed polynomial equation. The optimum response of the mass related to the variable optimization is presented in Table-4. The optimum values of the process variables were then verified using the experimental data. Consequently, the experimental result of the product mass in these optimum concentrations was $14.625 \mathrm{mg}$ (Table-5). Here the difference between the optimum and experimental results in the mass of struvite $(\mathrm{K})$ was $0.96 \%$. Here, an accuracy of $99.04 \%$ could be obtained for estimating the response of struvite $(\mathrm{K})$ production. Also, these results give a good achievement of modeling and optimization of proses factors. Moreover, it can be used for elucidating the effect of selected factors and thus model validation with insignificance factors. Based on the results, an easy, simple, and cost-effective method for precipitation of valuable struvite (K) from the wastewater may be integrated as a basic process of potassium recovery for achieving sustainable development ${ }^{29-31}$. 
In engineered environments, phosphorus and potassium in wastewater may come from different sources, including urine, synthetic detergents, and household cleaning products ${ }^{32}, 33$. These chemical ingredients are important nutrient needed for cells, crops, living creatures, and human existence. At present, over $85 \%$ of those elements are used up for fertilizer production. With increases in the world population from 9 to 10 billion by 2050, the need for food containing more phosphorus and potassium would increases ${ }^{32}$. Here urine is potentially $\mathrm{P}$ and $\mathrm{K}$ sources for a stable and sustainable agriculture ${ }^{34}$. Due to inconvenient transportation and storage of urine in large scale, it is undesirable for direct using urine in the agriculture sector. Here the convenient and safe use requires concentrated and stabilized nutrients in urine through the formation of struvite $(\mathrm{K})$, in which $\mathrm{P}$ and $\mathrm{K}$ can be recovered simultaneously and used as a slowrelease fertilizer ${ }^{32}$. The use of a pilot-scale K-struvite fluidized bed reactor has been demonstrated for recovering $20-35 \% \mathrm{~K}$ and $80-90 \% \mathrm{P}$ from urine ${ }^{35}$.

Table-4: Optimum Factors and the Optimum Result of Precipitate Mass (mg)

\begin{tabular}{c|c|c}
\hline Factor & Optimum Values & Optimum Precipitate Mass (mg) \\
\hline Temperature $\left({ }^{\mathrm{O}} \mathrm{C}\right)$ & 39 & 14.485 \\
\hline Stirring rate $(\mathrm{rpm})$ & 376 & \\
\hline Citric acid Concentration $(\mathrm{ppm})$ & 2.235 & \\
\hline
\end{tabular}

Table-5: Optimum Factors and the Experimental and Calculated Result of Precipitate Mass (mg)

\begin{tabular}{c|c|c|c}
\hline Optimum Variables & $\begin{array}{c}\text { Calculated } \\
\text { Result }\end{array}$ & $\begin{array}{c}\text { Experimental Result } \\
\text { Mass (mg) }\end{array}$ & \% Disparity \\
\hline Temperature $\left({ }^{\circ} \mathrm{C}\right)$ & & & \\
\hline Stirring speed $(\mathrm{rpm})$ & 14.485 & 14.625 & $0.96 \%$ \\
\hline Citric acid Concentration $(\mathrm{ppm})$ & & & \\
\hline
\end{tabular}

Disparity $(\%)=[($ Experimental result - Calculated result $) /$ Calculated result $] \times 100 \%$

\section{CONCLUSION}

SRM optimization of the process parameters in the batch crystallizer provided the temperature being a significant factor in the mass yield of struvite $(\mathrm{K})$ crystal. The optimum result of the mass struvite (K) crystal $(14.485 \mathrm{mg})$ corresponded to the optimum parameters of temperature $\left(39^{\circ} \mathrm{C}\right)$, stirring rate $(376$ $\mathrm{rpm})$ and citric acid concentration (2235 ppm), respectively. Accordingly, modeling and optimization of struvite precipitation could be in good agreement. The effect of the selected factor and the model validation with insignificance factor could be also verified in the present study. Finally, these valuable results may be implemented in the precipitation technology of wastewater treatment to yield struvite $(\mathrm{K})$ which is rich in potassium.

\section{ACKNOWLEDGMENT}

The authors express their gratitude to the Universitas Pembangunan National "Veteran" Jawa Timur, Indonesia for supporting this research project. Partly supported by UNDIP Research Grant 2018 is also acknowledged.

\section{REFERENCES}

1. J.D. Doyle, S.A. Parsons, Water Res. 36, 3925 (2002), DOI:10.1016/S0043-1354(02)00126-4

2. A. Capdeviellea, E. Sykorová, B.Biscans, F.Bélinea, M-L. Daumer, J. Hazard. Mater. 244-245, 357 (2013), DOI: 10.1016/j.jhazmat.2012.11.054

3. K.N. Ohlinger, T.M. Young, E.D. Schroeder, J. Environ. Eng. 126, 361(2000), DOI: 10.1061/(ASCE)0733-9372(2000)126:4(361)

4. A. Kozik, N Hutnik,. K. Piotrowski, A. Matynia, Chem. Eng. Res. Des, 92, 481 (2014), DOI: 10.1002/cjce.5450680520

5. B.Cieślik, P. Konieczka, J. Clean. Prod., 142(4), 1728 (2017), DOI: 10.1016/j.jclepro.2017.10.005

6. R. Yu, H. Ren, Y. Wang, L. Ding, J. Geng, K. Xu, Y. Zhang, Bioresource Technology 143, 519 (2013), DOI: 10.1016/j.biortech.2013.06.042

7. Md. M. Rahman, M. A. M. Salleh, K. Rashid, A. Ahsan, M. M. Hossain, C. S. Ra, Arabian Journal of Chemistry, 7, 139 (2014), DOI:10.1016/j.arabjc.2013.10.007

8. M. Ronteltap, M. Maurer, W. Gujer, Water Res. 41, 977 (2007), DOI: 10.1016/j.watres.2006.11.046 
RASĀYAN J. Chem.

Vol. 12 | No. 2 |787-795| April - June | 2019

9. J. Wilsenach, C. Schuurbiers, M.C.M. van Loosdrecht, Water Res. 41, 458(2007), DOI: 10.1016/j.watres.2006.10.014

10. N. C. Bouropoulos, P. G. Koutsoukos, J. Cryst. Growth, 213, 381 (2000), DOI:10.1016/S00220248(00)00351-1

11. I. Stratful, M.D. Scrimshaw, J.N. Lester, Water Res. 35, 4191 (2001), DOI: 10.1016/S00431354(01)00143-9

12. J.D. Doyle, K. Oldring, J.Churchley, C.Price, S.A. Parsons, J. Environ. Eng. - ASCE, 129, 419 (2003), DOI: 10.1061/(ASCE)0733-9372(2003)129:5(419)

13. S. Muryanto, A.P. Bayuseno, Powder Technol. 253, 602 (2014), DOI: 10.1016/j.powtec.2013.12.027

14. I. Stratful, M.D. Scrimshaw, J.N. Lester, Water Environ. Res. 76, 437 (2004), DOI: 10.2175/106143004X151491

15. K. Suzuki, Y.Tanaka, K.Kuroda, D.Hanajima, Y.Fukumoto, Bioresource Technology, 96, 1544 (2005), DOI: 10.1016/j.biortech.2004.12.017

16. K. Suzuki, Y. Tanaka, K. Kuroda, D. Hanajima, Y. Fukumoto, T. Yasuda, M. Waki, Bioresource Technology, 98, 1573 (2007), DOI: 10.1016/j.biortech.2006.06.008

17. S.B. Moussa, M.M.Tlili, N. Batis, M.B. Amor, Cryst. Res. Technol. 46, 255(2011),DOI: 10.1002/crat.201000571

18. A.N. Kofina, K.D. Demadis, P.D. Koutsoukos, Cryst. Growth Des. 7, 2705 (2007),DOI: $10.1021 / \mathrm{cg} 0603927$

19. Y. Song, Y.Dai, Q.Hu, X.Yu, F.Qian, Chemosphere, 101, 41(2014),DOI: 10.1016/j.chemosphere.2013.11.019

20. T.Rabizadeh, C. L.Peacock, L. G Benning. Mineralogical Magazine 78, 1465(2014), DOI:10.1180/minmag.2014.078.6.01

21. D.S. Perwitasari, L. Edahwati, S. Sutiyono, S. Muryanto, J. Jamari, A. P. Bayuseno Environ. Technol. 38, 2844 (2017), DOI: 10.1080/09593330.2017.1278795

22. M.S. Rahaman, N. Ellis, D.S. Mavinic, Water Sci. Technol. 57, 647 (2008), DOI: 10.2166/wst.2008.022

23. H.A. El-Gawad, I.A. Kattab, A.N. Mahdy, H. Moselhy, O.A. Ibrahim, RJPBCS, 8, 1366 (2017).

24. K Xu, J. Li, M. Zheng, C. Zhang, T.Xie, C. Wang. Water Res. 80, 71 (2015), DOI: 10.1016/j.watres.2015.05.026

25. S. Graeser, W. Postl, H-P. Bojar, P. Berlepsch, T. Armbruster, T. Raber, K. Ettinger, F. F. Walter, European Journal of Mineralogy 20, 629 (2008), DOI: 10.1127/0935-1221/2008/0020

26. H.M. Rietveld, J. Appl. Crystallogr. 2, 65 (1969), DOI: 10.1107/S0021889869006558

27. J. Rodriguez-Carvajal Program Fullprof.2k, version 3.30, Laboratoire Leon Brillouin, France, June 2005.

28. C. K. Chauhan, P. Vyas, M. J. Joshi, Cryst. Res. Technol., 46, 187 (2011), DOI: 10.1002/crat.201000587

29. L. Edahwati, S. Sutiyono, S. Muryanto, J. Jamari, A. P. Bayuseno, Rasayan J. Chem., 11(2), 904 (2018), DOI: $10.31788 /$ RJC.2018.1123007

30. S.K. Sharma, A. Chaudharyb, R.V. Singh, Rasayan J. Chem., 1, 68 (2008)

31. N. K. Swamy, P. Singh, I. P. Sarethy, Rasayan J. Chem., 4, 452 (2011)

32. K. Xu, J. Li, M. Zheng, C. Zhang, T. Xie, C. Wang, Water Res., 80, 71 (2015), DOI: 10.1016/j.watres.2015.05.026

33. K. Xu, C. Zhang, J. Li, X. Cheng, C. Wang, Water Sci. Technol., 75(1), 155 (2017), DOI: 10.2166/wst.2016.494

34. K.M. Udert, M. Wächter, Water Res., 46, 453 (2012), DOI: 10.1016/j.watres.2011.11.020

35. C. Zhang, K Xu, J. Li, C. Wang, M. Zheng, Ind. Eng. Chem. Res., 56(11), 5653033 (2017), DOI: 10.1021/acs.iecr.6b04819

[RJC-5125/2018] 